\title{
Non-Neoplastic Lip Disorder
}

National Cancer Institute

\section{Source}

National Cancer Institute. Non-Neoplastic Lip Disorder. NCI Thesaurus. Code C79544.

A non-neoplastic disorder that affects the lips. Representative examples include

inflammation and cleft lip. 